Meiske Wenno

\title{
Analisis Kinerja Keuangan Menggunakan Rasio Keuangan dan Economic Value Added (EVA) pada PT.Indocement Tunggal Prakarsa Tbk (Periode 2015-2019)
}

\author{
Meiske Wenno \\ Universitas Pattimura \\ meiske46@gmsil.com
}

\begin{abstract}
Abstrak
Tujuan penelitian ini adalah untuk mengukur prestasi yang dicapai oleh PT Indocement dalam suatu periode tertentu serta menilai Kinerja Keuangan PT Indocemen Tunggal Prakarsa Tbk periode 2015-2019 menggunakan rasio keuangan dan Economic Value Added (EVA). Periode penelitian ini dilakukan selama 5 tahun yaitu tahun 2015-2019. Metode penelitian yang digunakan dalam penulisan ini adalah metode deskriptif kuantitatif. Objek penelitian ini adalah PT Indocemen Tunggal Prakarsa Tbk.

Hasil analisis menunjukan bahwa kinerja PT Indocemen Tunggal Prakarsa dari rasio likuiditas belum baik hal ini ditunjukan dari rata-rata rasio lancar sebesar 4.06 kali dan ratarata rasio cepat sebesar 3.53 kali. Rasio aktivitas juga belum baik ditunjukan dari rasio perputaran persediaan dengan rata-rata rasio sebesar 1,002 kali dan rasio perputaran aktiva dengan rata-rata sebesar 1,022 kali serta rasio fixed asset turn over dengan rata-rata rasio sebanyak 0,550 kali. Pada rasio leverage yang diukur menggunakan rasio debt to asset ratio dengan rata-rata $15 \%$ dan rasio debt to equity ratio dengan rata-rata sebesar $17 \%$ menunjukan kinerja yang baik pada rasio ini. Pada rasio profitabilitas kemampuan memperoleh laba diukur menggunakan rasio net profit margin dapat dilihat bahwa rata-rata rasio sebesar $18 \%$ dan pada rasio retrun on equity memiliki rata-rata rasio sebesar $10 \%$, serta rasio retrun on ivestmen memiliki rata-rata rasio sebesar $11 \%$. Kinerja yang dihasilkan dalam memperoleh laba dikatakan tidak baik.
\end{abstract}

Kata Kunci: Rasio Keuangan, EVA

\section{Pendahuluan}

Parameter untuk menilai tingkat kinerja keuangan perusahaan antara lain rasio keuangan dan Economic value added (EVA). Analisis rasio keuangan ini sangat membantu dalam menilai kekuatan dan kelemahan kinerja keuangan di masa lalu dan prospeknya di masa yang akan datang. Melalui analisis rasio juga dapat diukur apakah perusahaan dapat membayar kewajiban jangka pendeknya, apakah besarnya piutang pada perusahaan cukup rasional, sejauh mana efisiensi dan efektivitas pendayagunaan seluruh aktiva yang dimiliki perusahaan, serta bagaimana kemampuan perusahaan untuk memperoleh laba. Rasio-rasio keuangan memberikan informasi yang sederhana mengenai hubungan antar pos tertentu dengan pos lainnya sehingga memudahkan dan mempercepat dalam menilai kesehatan dan kinerja perusahaan (Sulistyowati, 2015).

Sedangkan konsep Economic Value Added (EVA) digunakan untuk melakukan pengukuran kinerja yang berdasarkan nilai (value) karena EVA adalah ukuran nilai tambah ekonomis yang dihasilkan oleh perusahaan sebagai akibat dari aktivitas atau strategi 


\section{Meiske Wenno}

manajemen. Dengan adanya EVA, maka pemilik perusahaan hanya akan memberikan imbalan (reward) terhadap aktivitas yang menambah nilai dan membuang aktivitas yang merusak atau mengurangi nilai keseluruhan pada perusahaan. EVA merupakan pendekatan dalam menilai kinerja perusahaan dengan memperhatikan secara adil ekspektasi penyandang dana atau investor. EVA adalah laba yang tertinggal setelah dikurangi biaya modal (cost of capital) yang di investasikan untuk menghasilkan laba tersebut. Nilai EVA yang positif dapat diartikan bahwa manajemen perusahaan tersebut telah menciptakan nilai (creating value). Sebaliknya apabila nilai EVA negatif diartikan bahwa tidak ada nilai tambah ekonomis ke dalam perusahaan.

PT. Indocement Tunggal Prakarsa Tbk. Terkenal dengan merek "Tiga Roda" dan merek baru "Rajawali", Dalam kurun waktu 10 tahun setelah beropersinya pabrik pertama, perseroan membangun 7 pabrik tambahan sehingga kapasitas produksi terpasangnya meningkat menjadi 7,7 ton per tahun. Peningkatan tersebut turut membantu penyediaan pasokan semen bagi pembangunan di Indonesia yang semula merupakan negara importir semen, berubah menjadi negara yang mampu mengekspor semen, memproduksi beton siap pakai serta mengelola tambang agregat dan tras, kini Indocement merupakan produsen terbesar ke dua di Indonesia, namun persaingan yang ketat terjadi bukan saja terjadi antara pemain lama namun hadirnya pemain baru yang mengharuskan Indocement menyiapkan segala persiapan untuk menghadapi tantangan yang akan datang.

Kondisi Neraca keuangan PT. Indocement Tunggal Prakarsa Tbk. Tahun 2015 - 2019. Total asset tahun 2015 - 2019 mengalami fluktuasi setiap tahunnya sebesar $1.09 \%, 1.04 \%$, $0.96 \%$ dan $1.05 \%$ hal ini disebabkan oleh meningkatnya aktiva lancar dan aktiva tetap perusahaan. Total hutang pada tahun 2015 - 2019 juga mengalami fluktuasi setiap tahun sebesar 0,94\%, 0.93\%, 0,94\% dan 1.14\%. Dari sisi income statement (laporan laba rugi) PT. Indocement Tunggal Prakarsa Tbk tahun 2015 - 2019, laba bersih mengalami penurunan di tahun 2016 sebesar 11,16\% dan tahun 2017 turun sebesar 51,95\%. Tahun 2018 laba terus menurun sebesar 38,38\% dan kembali turun pada tahun 2019 sebesar 0,97\%. Penurunan laba perusahaan disebabkan oleh perlambatan ekonomi yang membuat permintaan semen nasional menurun sehingga penjualan perusahaan juga menurun, selain itu penambahan kapasitas terpasang yang tinggi membutuhkan beban usaha yang besar sehingga memberikan tekanan yang lebih besar terhadap harga jual, penjualan semen menunjukan pertumbuhan sebesar 4,4\% atau 717 ribu ton di tahun 2018 bila dibandingkan dengan tahun sebelumnya, ditengah permintaan semen nasional yang melonjak kondisi kelebihan kapasitas ini menyebabkan pangsa pasar perusahaan menuurun. Selain itu, dengan meningkatnya biaya produksi yang dipicu oleh kenaikan harga beli batu bara, bahan bakar minyak yang naik, harga kertas untuk kantong semen yang naik, juga melemahnya nilai tuka rupiah yang menjadi menurunnya keuntungan. Hal ini memang belum menggambarkan kinerja keuangan PT. Indocement Tunggal Prakarsa Tbk secara keseluruhan oleh sebab itu perlu dilakukan analisis lebih lanjut dari aspek keuangannya, terutama berdasarkan data yang diperoleh dari laporan keuangan PT. Indocement Tunggal Prakarsa Tbk (periode 2015-2019). Analisis rasio keuangan dan Economic Value Added (EVA) dapat memberikan penilaian terhadap kinerja keuangan. Tujuan yang ingin dicapai dari ke dua analisis ini adalah untuk mengetahui kinerja keuangan pada PT. Indocement Tunggal Prakarsa Tbk (periode 2015-2019). 


\section{Landasan Teori}

\section{Pengertian dan Tujuan Laporan Keuangan}

Menurut Munawir (2010:2) "Laporan keuangan pada dasarnya adalah hasil dari proses akuntansi yang dapat digunakan sebagai alat untuk berkomunikasi antara data keuangan atau aktivitas suatu perusahaan dengan pihak-pihak yang berkepentingan dengan data atau aktivitas perusahaan tersebut". Bambang Riyanto (2008:327) menyatakan bahwa Laporan keuangan memberikan ikhtisar mengenai keadaan finansial suatu perusahaan, dimana neraca (balance sheet) mencerminkan nilai aktiva, utang dan modal sendiri pada suatu saat tertentu, dan laporan rugi dan laba (income statement) mencerminkan hasil-hasil yang dicapai selama suatu periode tertentu biasanya meliputi periode satu tahun.(Wibowo, 2013). Sedangkan tujuan laporan keuangan yaitu untuk menyediakan informasi yang berkaitan dengan posisi keuangan, prestasi (hasil usaha) perusahaan serta perubahan posisi keuangan suatu perusahaan yang bermanfaat bagi pemakai dalam pengambilan keputusan ekonomi.

\section{Pengertian Kinerja Keuangan.}

pada empat perspektif keuangan, yaitu customer, proses, pembelajaran dan pertumbuhan. Menurut Mulyadi (2007:415) yang menyebutkan bahwa "Kinerja keuangan adalah penentuan secara periodik efektivitas operasional suatu organisasi dan karyawannya berdasarkan sasaran, standar dan kriteria yang telah Secara umum dapat dikatakan bahwa kinerja keuangan adalah prestasi yang dapat dicapai oleh perusahaan dibidang keuangan dalam suatu periode tertentu yang mencerminkan tingkat kesehatan perusahaan. Disisi lain kinerja keuangan menggambarkan kekuatan struktur keuangan suatu perusahaan dan sejauh mana asset yang tersedia, perusahaan sanggup meraih keuntungan. Hal ini berkaitan erat dengan kemampuan manajemen dalam mengelola sumber daya yang dimiliki perusahaan secara efektif dan efisien.(Wibowo, 2013)

\section{Pengertian Rasio keuangan}

Rasio keuangan merupakan teknik analisis dalam bidang manajemen keuangan yang dimanfaatkan sebagai alat ukur kondisi keuangan suatu perusahaan dalam periode tertentu, ataupun hasil-hasil usaha dari suatau perusahaan pada satu periode tertentu dengan jalan membandingkan dua buah variabel yang diambil dari laporan keuangan perusahaan, baik daftar neraca maupun laba rugi.

\section{Analisis Rasio Keuangan}

Menurut Kasmir (2013) dalam (Kerihi, 2019) "Rasio keuangan merupakan indeks yang menghubungkan dua angka akuntansi dan diperoleh dengan membagi satu angka dengan angka lainnya. Rasio keuangan digunakan untuk mengevaluasi kondisi keuangan dan kinerja perusahaan. Hasil rasio keuangan ini akan terlihat kondisi kesehatan perusahaan yang bersangkutan". Sedangkan analisis rasio keuangan memberikan gambaran terhadap indikasi prospek perusahaan di masa mendatang, selain itu hasil analisis akan lebih bermanfaat apabila dibandingkan dengan hasil analisis rasio keuangan perusahaan sejenis dan dengan standar yang telah ditentukan. Dengan analisis keuangan juga akan dapat diketahui apakah perusahaan yang satu mempunyai kinerja yang lebih baik dibandingkan dengan perusahaan yang lain. Dalam hubungannya dengan kinerja perusahaan, analisis terhadap rasio-rasio keuangan akan lebih 


\section{Meiske Wenno}

bermakna jika laporan keuangan yang digunakan dalam analisis tersebut lebih dari satu periode atau tahun, karena dapat dilihat tingkat kestabilan kinerja keuangan pada beberapa tahun yang dianalisis.(Isti Fadah, Markus Apriono, 2005)

\section{Jenis-jenis Rasio Keuangan}

Menganalisis laporan keuangan berarti mengevaluasi tiga karakteristik dari perusahaan, yaitu likuiditas, leverage, aktivitas, profitabilitas yang menjadi faktor penting yang harus diperhatikan oleh penganalisa.

1. Rasio likuiditas adalah rasio yang mengukur kemampuan perusahaan memenuhi kewajiban jangka pendeknya (Hanafi,2009:74). Rasio likuiditas digunakan untuk mengukur seberapa likuidnya suatu perusahaan dengan cara membandingkan komponen yang ada di neraca yaitu total aktiva lancar dan pasiva lancar

a. Rasio Lancar (Current Rasio)

Rasio lancar merupakan rasio untuk mengukur kemampuan suatu perusahaan dalam memenuhi kewajiban jangka pendeknya atau hutang yang segera jatuh tempo pada saat ditagih secara keseluruhan dengan aktiva lancar yang dimilikinya, yaitu dengan perbandingan antara jumlah aktiva lancar dengan hutang lancar. Menurut (Hanafi, 2016) Rasio Lancar untuk perusahaan yang normal berkisar dengan standar pada angka 2 atau $200 \%$.

b. Rasio Cepat (Quick Ratio)

Rasio ini menujukkan kemampuan perusahaan untuk membayar hutang lancar (hutang jangka pendek) yang harus segera dipenuhi dengan aktiva lancar yang tersedia dalam perusahaan tanpa memperhitungkan nilai persediaan (inventory). Rasio quick untuk perusahaan yang normal berkisar pada standar angka 1,5 (Kasmir, 2008)

2. Rasio Solvabilitas adalah "rasio yang mengukur sejauh mana aktiva perusahaan dibiayai dengan utang" (Kasmir 2015:151). Sedangkan menurut Munawir (2010:32), rasio solvabilitas "Menunjukkan kemampuan perusahaan untuk memenuhi keuangannya apabila perusahaan tersebut dilikuidasikan baik kewajiban keuangan jangka pendek maupun jangka panjang”.

a. Rasio Hutang Terhadap Total Aktiva (Debt To Asset Ratio)

Rasio ini menunjukkan seberapa besar dari keseluruhan aktiva perusahaan yang dibelanjai oleh hutang atau seberapa besar proporsi antara kewajiban yang dimiliki dengan kekayaan yang dimiliki. Standar industry yang baik sebesar 35\%.(Kasmir, 2008)

b. Rasio Hutang Terhadap Ekuitas (Debt To Equity Ratio)

Rasio ini digunakan untuk menilai hutang dengan ekuitas sehingga rasio ini berguna untuk mengetahui jumlah dana yang disediakan pinjaman (kreditor) dengan pemilik perusahaan. DER yang baik harus bernilai rendah dari standar industri yaitu 90\%.(Kasmir, 2008)

3. Rasio aktivitas menunjukan kemampuan perusahaan untuk mengukur seberapa efektif hasil guna perusahaan menggunakan sumber dayanya (Hanafi, 2009:74).

a. Perputaran Persediaan (Inventory Turn Over)

Rasio perputaran untuk perusahaan yang normal sebanyak 20 kali dalam setahun. Rasio ini digunakan untuk mengukur berapa kali dana yang ditanam dalam persediaan berputar dalam suatu periode.(Kasmir, 2008) 


\section{Meiske Wenno}

b. Fixed Asset Turn Over

Rasio ini merupakan rasio yang digunakan untuk mengukur berapa kali dana yang ditanamkan dalam aktiva tetap berputar dalam satu periode. Standar industri untuk rasio ini sebanyak 5 kali dalam setahun.(Kasmir, 2008)

c. Perputaran Total Aktiva (Total Asset Turn Over)

Total Asset Turn Over merupakan rasio yang digunakan untuk mengukur perputaran semua aktiva yang dimiliki perusahaan dan mengukur berapa hasil penjumlahan yang diperoleh dari tiap rupiah aktiva. Standar rasio yang baik sebesar 2 kali dalam setahun. (kasmir,2008).

4. Rasio Profitabilitas menurut Munawir (2010:33) menunjukkan kemampuan perusahaan untuk menghasilkan laba selama periode tertentu".

a. Net Profit Margin

Net Profit Margin merupakan rasio yang digunakan untuk mengukur margin laba bersih setelah bunga dan pajak atas penjualan neto pada suatu periode tertentu. Standar rata rata industry untuk rasio ini adalah $20 \%$. (Kasmir,2008)

b. Hasil pengembalian Investasi (Return On Investment)

Return On Investment rasio ini mengukur keuntungan yang diperoleh dari hasil kegiatan perusahaan (Net Income) dengan jumlah investasi atau aktiva yang digunakan setelah dikurangi bunga dan pajak untuk menghasilkan keuntungan yang diinginkan. standar industri yang baik untuk rasio ini adalah 30\%.(Kasmir, 2008)

c. Hasil pengembalian Ekuitas (Return On Equity)

Hasil pengembalian ekuitas atau Return On Equity atau rentabilitas modal sendiri merupakan rasio untuk mengukur laba bersih (Net Income) sesudah pajak dengan modal sendiri. Menurut Kasmir standar industri untuk rasio ini adalah 40\%. (Kasmir, 2008).

\section{Economic Value Added (EVA)}

Economic value added (EVA) merupakan indikator tentang adanya perubahan nilai dari suatu investasi. Economic value added (EVA) yang positif menunjukkan bahwa manajemen perusahaan berhasil meningkatkan nilai perusahaan bagi pemilik perusahaan sesuai dengan tujuan manajemen keuangan dalam memaksimumkan nilai perusahaan (Sawir, 2001). Young dan O'Bryne (2001), menyatakan bahwa EVA didasarkan pada gagasan keuntungan ekonomis yang menyatakan, bahwa kekayaan hanya diciptakan ketika sebuah perusahaan meliputi biaya operasi dan biaya modal. Berdasarkan kutipan diatas, maka economic value added (EVA) adalah penciptaan nilai tambah perusahaan yang digunakan untuk mengukur peningkatan investasi bagi pemegang saham.

Rudianto (2006:348) dalam EVA, penilaian kinerja keuangan diukur dengan ketentuan:

1. Jika EVA > 0, maka kinerja keuangan perusahaan dapat dikatakan baik, sehingga terjadi proses perubahan nilai ekonomisnya.

2. Jika EVA $=0$, maka kinerja keuangan perusahaan secara ekonomis dalam keadaan impas.

3. Jika EVA $<0$, maka kinerja keuangan perusahaan tersebut dikatakan kurang bagus karena laba yang diperoleh tidak memenuhi harapan penyandang dana, sehingga tidak terjadi penambahan nilai ekonomis pada perusahaan. 


\section{Meiske Wenno}

Setiap perusahaan tentunya menginginkan nilai EVA akan naik terus menerus, karena EVA adalah tolak ukur fundamental dari tingkat pengembalian modal (return of capital). Ada beberapa cara untuk meningkatkan nilai EVA perusahaan yaitu,Widayanto (1993:32-33):

1. Meningkatkan keuntungan (profit) tanpa menambah modal

2. Menurangi pemakaian modal

3. Melakukan investasi pada proyek-proyek dengan tingkat pengembalian tinggi.

EVA dilandasi pada konsep bahwa dalam pengukuran laba suatu perusahaan harus adil dengan mempertimbangkan harapan-harapan setiap penyandang dana (kreditur dan pemegang saham). Young dan O’Bryne (2001:32) memformulasikan EVA sebagai berikut:

EVA = Laba operasi bersih setelah pajak (NOPAT) - Biaya modal

NOPAT $=$ Laba operasi sebelum pajak - Pajak penghasilan

Biaya Modal $=$ Modal yang diinvestasikan $\mathrm{x}$ Biaya modal rata-rata tertimbang

\section{Metode Penelitian}

\section{Ruang Lingkup Penelitian}

Penelitian ini dilakukan untuk menganalisis kinerja keuangan perusahaan dengan menggunakan rasio keuangan dan metode Economic value added (EVA) pada PT Indocement Tunggal Prakarsa, Tbk yang merupakan industri penghasil semen di Indonesia. Data diambil dari tahun 2015 sampai dengan tahun 2019.

\section{Sumber Data}

Data yang digunakan dalam penelitian ini adalah data sekunder berupa data yang bersumber dari website resmi Bursa Efek Indonesia (www.idx.co.id) berupa data laporan keuangan PT Indocement Tunggal Prakarsa, Tbk dan dilengkapi studi kepustakaan.

\section{Teknik Analisis Data}

Adapun alat analisis yang digunakan antara lain:

1. Rasio Keuangan

a. Rasio Likuiditas

Rasio likuiditas merupakan rasio yang menggambarkan kemampuan perusahaan dalam memenuhi kewajiban jangka pendeknya.

1. Rasio Lancar (Current Ratio)

$$
C R=\frac{\text { Aktiva lancar }}{\text { Hutang lancar }} \times 100 \%
$$

2. Rasio Cepat (Quick Ratio)

$$
Q R=\frac{\text { Aktiva lancar }- \text { Persediaan }}{\text { Hutang lancar }} \times 100 \%
$$


b. Rasio Solvabilitas

Rasio solvabilitas Rasio solvabilitas merupakan rasio yang digunakan untuk mengukur sejauh mana aktiva perusahaan dibiayai dengan utang.

1. Debt To Asset Ratio

$$
D A R=\frac{\text { Total Kewajiban }}{\text { Total Aktiva }} \times 100 \%
$$

2. Debt To Equity Ratio

$$
D A R=\frac{\text { Total Kewajiban }}{\text { Total Aktiva }} \times 100 \%
$$

c. Rasio Aktivitas

Rasio Aktivitas, yaitu rasio yang mengukur sejauh mana efektivitas penggunaan aset dengan melihat tingkat aktivitas aset.

1. Inventory Turn Over

$$
I T O=\frac{\text { Penjualan }}{\text { Persediaan }} \times 1 \text { Kali }
$$

2. Fixed Asset Turn Over

$$
F A T O=\frac{\text { Penjualan }}{\text { Aktiva Tetap }} \times 1 \text { Kali }
$$

3. Total Asset Turn Over

$$
\text { TATO }=\frac{\text { Penjualan }}{\text { Total Aktiva }} \times 1 \text { Kali }
$$

d. Rasio Profitabilitas

Rasio profitabilitas merupakan rasio untuk menialai kemampuan perusahaan dalam menghasilkan keuntungan.

1. Net Profit Margin

$$
N P M=\frac{\text { Laba Bersih }}{\text { Penjualan }} \times 100 \%
$$

2. Return On Investment

$$
R O I=\frac{\text { Laba Bersih }}{\text { Total Aktiva }} \times 100 \%
$$

3. Return On Equity

$$
R O E=\frac{\text { Laba Bersih }}{\text { Modal Sendiri }} \times 100 \%
$$

2. Economic Value Added (EVA)

Langkah-langkah dalam perhitungan EVA antara lain:

1) Menghitung NOPAT (Net Operating After Tax)

NOPAT = Laba Sebelum Pajak - Pajak

2) Menghitung Invest Capital (Total Modal Yang Diinvestasikan)

Invest Capital $=($ Total Hutang + Equity $)-$ Hutang Jangka Pendek

3) Menghitung WACC (Weight Average Cost of Capital)

$\boldsymbol{W A C C}=[\boldsymbol{D} \times \boldsymbol{r d}(\mathbf{1}-\boldsymbol{T})]+(\boldsymbol{E} \times \boldsymbol{r e})$ 


\section{Meiske Wenno}

Ket:

a. Identifikasi tingkat modal dari hutang (D)

$$
\boldsymbol{D}=\frac{\text { Total Hutang }}{\text { Total Hutang \& Ekuitas }} \times 100 \%
$$

b. Identifikasi biaya hutang (rd)

$$
\boldsymbol{r d}=\frac{\text { Biaya Bunga }}{\text { Total Hutang }} \times 100 \%
$$

c. Menentukan presentasi pajak penghasilan (T)

$$
\boldsymbol{T}=\frac{\text { Beban Pajak }}{\text { Laba Sebelum Pajak }} \times 100 \%
$$

d. Menghitung Cost of Equity (re)

$$
\boldsymbol{r e}=\frac{\text { Laba Bersih Setelah Pajak }}{\text { Total Ekuitas }} \times 100 \%
$$

e. Menerukan tingkat modal dari ekuitas (E)

$$
\boldsymbol{E}=\frac{\text { Total Ekuitas }}{\text { Total Hutang \& Ekuitas }} \times 100 \%
$$

4) Menghitung Biaya Modal (Capital Charge)

Capital Charge $=W A C C x$ Invest Capital

5) Menghitung EVA (Economic Value Added)

$\boldsymbol{E V} \boldsymbol{A}=$ NOPAT - Capital Charge

\section{Pembahasan}

Berdasarkan laporan keuangan PT. Indocement Tunggal Prakarsa Tbk yang di lihat dari income statement dan balance sheet tahun 2015 sampai dengan tahun 2019 maka diperoleh hasil analisis laporan keuangan yang menggunakan alat analisis rasio keuangan seperti tabel berikut:

Tabel 1 Hasil Perhitungan Analisis Rasio Keuangan PT. Indocement Tunggal Prakarsa, Tbk Tahun 2015 - 2019

\begin{tabular}{|c|c|c|c|c|c|c|c|c|c|c|}
\hline Tahun & $\begin{array}{c}\text { Current } \\
\text { Ratio } \\
(\boldsymbol{\%})\end{array}$ & $\begin{array}{c}\text { Quick } \\
\text { Ratio } \\
(\boldsymbol{\%})\end{array}$ & $\begin{array}{c}\text { Debt to } \\
\text { Asset } \\
\text { Ratio } \\
(\boldsymbol{\%})\end{array}$ & $\begin{array}{c}\text { Debt to } \\
\text { Equity } \\
\text { Ratio } \\
(\boldsymbol{\%})\end{array}$ & $\begin{array}{c}\text { Inventor } \\
\mathbf{y} \text { Turn } \\
\text { Over } \\
\text { Ratio (x) }\end{array}$ & $\begin{array}{c}\text { Fixed } \\
\text { Asset } \\
\text { Turn } \\
\text { Over } \\
\text { Ratio (x) }\end{array}$ & $\begin{array}{c}\text { Total } \\
\text { Aset } \\
\text { Turn } \\
\text { Over } \\
\text { Ratio (x) }\end{array}$ & $\begin{array}{c}\text { Net } \\
\text { Profit } \\
\text { Margin } \\
(\boldsymbol{\%})\end{array}$ & $\begin{array}{c}\text { Return } \\
\text { On } \\
\text { Equity } \\
(\boldsymbol{\%})\end{array}$ & $\begin{array}{c}\text { Return } \\
\text { On } \\
\text { Invest } \\
\text { men } \\
(\%)\end{array}$ \\
\hline$(1)$ & $(2)$ & $(3)$ & $(4)$ & $(5)$ & $(6)$ & $(7)$ & $(8)$ & $(9)$ & $(10)$ & $(11)$ \\
\hline 2015 & 488,66 & 428,81 & 14 & 16 & 11,1 & 1,2 & 0,6 & 24 & 18 & 16 \\
\hline 2016 & 452,50 & 396,65 & 13 & 15 & 8,6 & 1,0 & 0,5 & 25 & 15 & 13 \\
\hline 2017 & 370,31 & 319,47 & 15 & 18 & 8,2 & 0,9 & 0,5 & 13 & 8 & 6 \\
\hline 2018 & 313,73 & 266,91 & 16 & 20 & 8,3 & 1,0 & 0,5 & 8 & 5 & 4 \\
\hline 2019 & 346,89 & 289,46 & 15 & 17 & 5,9 & 0,8 & 0,4 & 10 & 5 & 4 \\
\hline $\begin{array}{c}\text { Rata- } \\
\text { rata }\end{array}$ & $\mathbf{3 9 4 , 4 2}$ & $\mathbf{3 4 0 , 2 6}$ & $\mathbf{1 5}$ & $\mathbf{1 7}$ & $\mathbf{8 , 4 2}$ & $\mathbf{0 , 9 8}$ & $\mathbf{0 , 5}$ & $\mathbf{1 6}$ & $\mathbf{1 0 , 2}$ & $\mathbf{8 , 6}$ \\
\hline
\end{tabular}

Sumber: Data diolah (2020) 


\section{Meiske Wenno}

Dari tabel di atas dapat dijelaskan bahwa:

1. Current ratio PT. Indocement tunggal prakarsa tbk dari tahun 2015 - 2018 mengalami penurunan dan pada tahun 2019 mengalami kenaikan sebesar 10,57\% dengan rata-rata current ratio PT. Indocement Tunggal Prakarsa Tbk sebesar 406,30\% yang berarti bahwa setiap Rp. 1,- hutang lancar yang perusahaan miliki dapat dibiayai oleh aktiva lancar sebesar Rp. 4,06,-. Pada tahun 2015 current ratio PT. Indocement tunggal prakarsa tbk adalah 488,66\% kemudian turun pada tahun 2016 yaitu 452,50\%. Pada tahun 2017 current ratio PT. Indocement Tunggal Prakarsa Tbk turun sebesar 370,31\% dan mengalami penurunan juga pada tahun 2018 sebesar 313,73\% sedangkan pada tahun 2019 mengalami kenaikan menjadi 346,89\%. Sedangkan rata-rata current ratio PT. Indocement Tunggal Prakarsa Tbk sebesar 406,30\% lebih besar dari 200\% yang berarti perusahaan mempunyai kemampuan untuk memenuhi kewajiban lancar dari aktiva lancar yang perusahaan miliki sangat baik tetapi di sisi yang lain pencapaian nilai current ratio yang terlalu tinggi mengindikasikan perusahaan belum mampu mengalokasikan aktiva lancar secara baik dan optimal. Rasio lancar yang terlalu tinggi tidak baik bagi perusahaan karena menunjukan banyaknya dana menganggur di kas perusahaan yang pada akhirnya mengurangi kemampulabaan perusahaan.

2. Quick ratio PT. Indocement Tunggal Prakarsa Tbk dari tahun 2015 - 2018 mengalami penurunan dan pada tahun 2019 mengalami kenaikan sebesar 8,45\% sedangkan rata-rata quick ratio PT. Indocement Tunggal Prakarsa Tbk pada periode 2015 - 2019 sebesar $340,26 \%$ yang berarti setiap Rp.1,- hutang lancar perusahaan dapat dijamin oleh aktiva lancar tanpa persediaan sebesar Rp. 3,40,-. Pada tahun 2015 quick ratio PT. Indocement tunggal prakarsa tbk adalah 428,81\% dan turun pada tahun 2016 sebesar 396,65\%. Pada tahun 2017 quick ratio PT. Indocement tunggal prakarsa tbk turun sebesar 319,47\% dan pada tahun 2018 mengalami penurunan sebesar 266,91\% sedangkan pada tahun 2019 quick ratio PT. Indocement tunggal prakarsa tbk mengalami kenaikan sebesar 289,46\%. Sedangkan rata-rata quick ratio PT. Indocement Tunggal Prakarsa Tbk pada periode 2015 - 2019 sebesar 340,26\% berada di atas $150 \%$ yang berarti perusahaan memiliki kemampuan likuiditas yang baik atau perusahaan sangat mampu untuk memenuhi kewajiban jangka pendeknya dengan aktiva lancar yang dimiliki di luar persediaan.

3. Debt to asset ratio PT. Indocement Tunggal Prakarsa Tbk dari tahun 2015 - 2019 mengalami fluktuasi. Sedangkan rata-rata debt to asset ratio PT. Indocement Tunggal Prakarsa Tbk pada periode 2015 - 2019 adalah 15\% berarti setiap Rp.100,- pendanaan perusahaan, Rp.15,- dibiayai hutang dan Rp.85,- disediakan oleh pemegang saham. Debt to asset ratio meruapakan rasio hutang yang digunakan untuk mengukur perbandingan antara total hutang dan total aktiva. Pada tahun 2015 debt to asset ratio PT. Indocement tunggal prakarsa tbk adalah 14\% kemudian turun pada tahun 2016 yaitu 13\%. Pada tahun 2017 debt to asset ratio PT. Indocement tunggal prakarsa tbk mengalami kenaikan sebesar 15\% dan mengalami kenaikan pada tahun 2018 sebesar 16\%. Pada tahun 2019 debt to asset ratio PT. Indocement Tunggal Prakarsa Tbk kembali mengalami penurunan pada tahun 2019 sebesar 15\%. Sedangkan rata rata rasio adalah 15\% menunjukan jumlah komposisi pendanaan perusahaan yang dibiayai oleh hutang. Semakin kecil nilai rasio ini menunjukan kinerja perusahaan yang baik karena semakin sedikit perusahaan dibiayai oleh hutang. Secara teori, apabila perusahaan dilikuidasi perusahaan memiliki kemampuan untuk menutupi hutangnya dengan aktiva yang dimiliki. 


\section{Meiske Wenno}

4. Debt to equity ratio PT. Indocement Tunggal Prakarsa Tbk dari tahun 2015 - 2019 mengalami fluktuasi dengan nilai rasio tertinggi pada tahun 2018 yaitu sebesar $20 \%$. Sedangkan rata-rata debt to equity ratio PT. Indocement Tunggal Prakarsa Tbk pada periode 2015 - 2019 adalah $17 \%$ yang artinya kreditor menyediakan Rp.17,- untuk setiap Rp.100,- yang disediakan pemegaang saham atau perusahaan dalam aktivitasnya dibiayai oleh hutang sebesar $17 \%$. Debt to equity ratio merupakan rasio yang digunakan untuk menilai hutang dengan ekuitas dengan membandingkan seluruh hutang dan ekuitas. Pada tahun 2015 debt to equity ratio PT. Indocement Tunggal Prakarsa Tbk adalah 16\% turun pada tahun 2016 menjadi 15\%. Pada tahun 2017 debt to equity ratio PT. Indocement Tunggal Prakarsa Tbk mengalami kenaikan sebesar 18\% dan terus mengalami kenaikan pada tahun 2018 sebesar 20\%. Sedangkan pada tahun 2019 DER PT. Indocement Tunggal Prakarsa Tbk mengalami penurunan sebesar 17\%. Rata-rata DER sebesar 17\% berada di bawah 90k\% yang artinya rasio DER PT. Indocement Tunggal Prakarsa Tbk dalam kondisi baik. Nilai DER yang rendah menunjukan hutang atau kewajiban perusahaan lebih kecil dari seluruh asset yang dimiliki. Rasio DER yang rendah berarti proporsi pendanaan yang disediakan oleh kreditur lebih kecil dibandingkan dengan modal sendiri yang menunjukan sumber modal perusahaan tidak tergantung pihak ke tiga.

5. Debt to equity ratio PT. Indocement Tunggal Prakarsa Tbk dari tahun 2015 - 2019 berfluktuasi. Pada tahun 2015 inventory turn over ratio PT. Indocement Tunggal Prakarsa Tbk adalah 11,1 kali turun pada tahun 2016 menjadi 8,6 kali. Pada tahun 2017 inventory turn over ratio PT. Indocement Tunggal Prakarsa Tbk juga mengalami penurunan sebesar 8,2 kali dan mengalami kenaikan pada tahun 2018 sebesar 8,3 kali. Pada tahun 2019 nilai inventory turn over ratio PT. Indocement Tunggal Prakarsa Tbk turun menjadi 5,9 kali. Rata-rata inventory turn over ratio PT. Indocement Tunggal Prakarsa Tbk kurang dari 20 kali yaitu sebesar 8,42 kali yang berarti terdapat penumpukan persediaan barang yang dipoduksi atau dijual. Hal ini sesuai dengan realitas persaingan produk semen yang dihasilkan PT. Indocement Tunggal Prakarsa Tbk pada tahun penelitian yaitu terdapat 10 merek dagang baru karena meningkatnya impor semen dari luar negeri dengan penjualan dengan harga yang murah.

6. Fixed asset turn over ratio PT. Indocement Tunggal Prakarsa Tbk dari tahun 2015 - 2019 mengalami fluktuasi. Pada tahun 2015 fixed asset turn over ratio PT. Indocement Tunggal Prakarsa Tbk adalah 1,2 kali turun pada tahun 2016 menjadi 1,0 kali. Pada tahun 2017 fixed asset turn over ratio PT. Indocement Tunggal Prakarsa Tbk terus mengalami penurunan menjadi 0,9 kali dan naik pada tahun 2018 sebesar 1,0 kali sedangkan pada tahun 2019 turun menjadi 0,8 kali. Rata-rata fixed asset turn over ratio PT. Indocement Tunggal Prakarsa Tbk tahun 2015 - 2019 adalah 0,98 kali berada di bawah nilai 5 kali yang berarti perusahaan belum efektif dalam mengelola asset tetapnya untuk menghasilkan pendapatan.

7. Total asset turn over ratio PT. Indocement Tunggal Prakarsa Tbk dari tahun 2015 - 2019 mengalami fluktuasi yang tidak signifikan. Pada tahun 2015 total asset turn over ratio PT. Indocement Tunggal Prakarsa Tbk adalah 0,6 kali kemudian turun menjadi 0,5 kali pada tahun 2016, 2017 dan 2018 serta naik pada tahun 2019 sebesar 0,4 kali. Rata-rata total asset turn over ratio PT. Indocement Tunggal Prakarsa Tbk sebesar 0,5 kali di bawah 2 kali yang berarti perusahaan tidak efisien menghasilkan penjualan dari total asset yang dimiliki. Semakin kecil rasio ini semakin tidak baik bagi perusahaan karena aktiva perusahaan 


\section{Meiske Wenno}

berputar lambat menghasilkan laba atau perusahaan tidak efisien menggunakan aktiva untuk menghasilkan penjualan.

8. Net profit margin PT. Indocement tunggal prakarsa tbk dari tahun 2015 - 2019 mengalami fluktuasi. Pada tahun 2015 debt to asset ratio PT. Indocement Tunggal Prakarsa Tbk adalah 24\% kemudian naik pada tahun 2016 sebesar 25\%. Pada tahun 2017 rasio net profit margin PT. Indocement Tunggal Prakarsa Tbk mengalami penurunan menjadi $13 \%$ dan terus mengalami penurunan pada tahun 2018 menjadi 8\% sedangkan pada tahun 2019 net profit margin PT. Indocement Tunggal Prakarsa Tbk yaitu 10\%. Rata-rata net profit margin PT. Indocement Tunggal Prakarsa Tbk sebesar $16 \%$ yang berarti perusahaan masih rendah menghasilkan laba bersih dari penjualan perusahaan.

9. Return on equity ratio PT. Indocement Tunggal Prakarsa Tbk dari tahun 2015 - 2019 mengalami fluktuasi. Pada tahun 2015 rasio return on equity PT. Indocement Tunggal Prakarsa Tbk adalah 18\% kemudian turun pada tahun 2016 sebesar 15\%. Pada tahun 2017 rasio return on equity PT. Indocement Tunggal Prakarsa Tbk mengalami penurunan menjadi 8\% dan terus mengalami penurunan pada tahun 2018 dan tahun 2019 menjadi 5\%. Sedangkan rata-rata return on equity ratio PT. Indocement Tunggal Prakarsa Tbk sebesar $10,2 \%$ tidak baik karena nilainya di bawah $20 \%$. Nilai ROE yang rendah berarti tingginya biaya operasi perusahaan yang berpengaruh terhadap rendahnya laba yang dapat dihasilkan perusahaan.

10. Return on investment PT. Indocement Tunggal Prakarsa Tbk dari tahun 2015 - 2019 mengalami fluktuasi tiap tahunnya. Pada tahun 2015 rasio return on investment PT. Indocement Tunggal Prakarsa Tbk adalah 16\% kemudian turun pada tahun 2016 menjadi 13\%. Pada tahun 2017 rasio return on investment PT. Indocement Tunggal Prakarsa Tbk mengalami penurunan menjadi 6\% dan terus mengalami penurunan pada tahun 2018 dan tahun 2019 menjadi 4\%. Rata-rata rasio return on investment PT. Indocement Tunggal Prakarsa Tbk sebesar $8,6 \%$ berada di bawah $30 \%$ yang berarti rasio ini tidak baik. Investasi yang tidak efisien membuat keuntungan yang diperoleh perusahaan rendah, hal ini menunjukan kinerja perusahaan belum baik.

Analisis kinerja keuangan berdasarkan Economic Value Added (EVA) sebagai berikut:

\section{NOPAT (Net Operating After Tax)}

Tabel 2 Perhitungan NOPAT

\begin{tabular}{|c|c|c|c|}
\hline Tahun & EAT & $\begin{array}{c}\text { Beban } \\
\text { Bunga }\end{array}$ & NOPAT \\
\hline$(1)$ & $(2)$ & $(3)$ & $(4=2+3)$ \\
\hline 2015 & 5.645 .111 & 26.543 & 5.671 .654 \\
\hline 2016 & 3.870 .319 & 11.823 & 3.882 .142 \\
\hline 2017 & 1.859 .818 & 14.093 & 1.873 .911 \\
\hline 2018 & 1.145 .937 & 18.661 & 1.164 .598 \\
\hline 2019 & 1.175 .788 & 5.890 & 1.181 .678 \\
\\
Sumber : Data diolah, 2020
\end{tabular}




\section{Meiske Wenno}

Berdasarkan hasil perhitungan NOPAT (Laba Usaha setelah Pajak) pada table 5, diperoleh nilai NOPAT pada tahun 2015 adalah Rp 5.671.654,- dan pada tahun 2016 NOPAT mengalami penurunan sebesar 31,55\% yaitu turun menjadi Rp 3.882.142,-. Sedangkan pada tahun 2017 nilai NOPAT sebesar Rp. 1.873.911,- dan kembali turun di tahun 2018 sebesar $51,73 \%$ menjadi Rp. 1.164.598,-. Penurunan ini disebabkan karena turunnya laba bersih (EAT) dan beban keuangan. Tahun 2019 naik tidak signifikan sebesar 1,46\% atau sebesar Rp. $1.181 .678,-$.

\section{Invested Capital}

Tabel 3 Perhitungan Invested Capital

\begin{tabular}{|c|c|c|c|}
\hline Tahun & $\begin{array}{c}\text { Hutang dan } \\
\text { Ekuitas }\end{array}$ & $\begin{array}{c}\text { Hutang Jangka } \\
\text { Panjang }\end{array}$ & $\begin{array}{c}\text { Invested } \\
\text { Capital }\end{array}$ \\
\hline$(1)$ & $(2)$ & $(3)$ & $(4=2-3)$ \\
\hline 2015 & 27.638 .360 & 2.687 .743 & 24.950 .617 \\
\hline 2016 & 30.150 .580 & 3.187 .742 & 26.962 .838 \\
\hline 2017 & 28.863 .676 & 3.479 .024 & 25.384 .652 \\
\hline 2018 & 27.788 .562 & 3.925 .649 & 23.862 .913 \\
\hline 2019 & 26.378 .871 & 3.320 .512 & 23.058 .359 \\
\hline
\end{tabular}

Sumber : Data diolah, 2020

Pada tabel 3 diperoleh hasil perhitungan total modal yang dihasilkan (Invested Capital) PT. Indocement Tunggal Prakarsa Tbk yaitu pada tahun 2015 Invested Capital adalah sebesar Rp 24.950.617,- dan tahun 2016 naik sebesar 8,06\% yaitu Rp 26.962.838,--. Tahun 2017 Invested Capital sebesar Rp 25.384.652,- mengalami penurunan sebesar 5,85\% dan pada tahun 2018 modal yang diinvestasikan perusahaan kembali turun sebesar 5,99\% atau turun menjadi Rp 23.862.913,- dari tahun sebelumnya. Sedangkan pada tahun 2019 total modal yang diinvestasikan oleh PT. Indocement Tunggal Prakarsa Tbk turun sebesar 3,37\% yaitu menjadi Rp. 23.058.359,-

\section{WAAC (Weight Average Cost of Capital)}

Tabel 4 Perhitungan WACC

\begin{tabular}{|c|c|c|c|c|}
\hline \multicolumn{5}{|c|}{ WACC $=[\mathbf{D} * \mathbf{r d}(\mathbf{1 - t a x})+(\mathbf{E} * \mathbf{r e})]$} \\
\hline Tahun & D*rd & 1-T & E*re & WACC \\
\hline$(1)$ & $(2)$ & $(3)$ & $(4)$ & $(5)$ \\
\hline 2015 & 118.01 & -21.81 & 1576.31 & -997.86 \\
\hline 2016 & 70.56 & -5.64 & 1283.66 & 885.61 \\
\hline 2017 & 218.05 & -17.69 & 644.35 & -3212.68 \\
\hline 2018 & 99.97 & -17.16 & 412.38 & -1303.23 \\
\hline 2019 & 41.60 & -20.06 & 445.86 & -388.59 \\
\cline { 3 - 5 } & &
\end{tabular}

Sumber : Data diolah, 2020

Berdasarkan perhitungan WACC PT. Indocement Tunggal Prakarsa Tbk pada tabel 4, terlihat bahwa pada tahun 2015 biaya modal rata-rata tertimbang (WACC) perusahaan adalah sebesar $-997,86 \%$, pada tahun 2016 meningkat sebesar 188,75\% sehingga WACC tahun 2016 adalah sebesar $885,61 \%$. Pada tahun 2017, WACC perusahaan turun menjadi $-3212,68 \%$ atau turun sebesar $462,77 \%$ dari tahun 2016. Penurunan WACC ini disebabkan oleh penurunan 


\section{Meiske Wenno}

ekuitas dan biaya ekuitas. Pada tahun 2018, WACC perusahaan sebesar $-1303,23 \%$ dan pada tahun 2019 WACC sebesar $-388,59 \%$. Berdasarkan uraian diatas, terlihat bahwa WACC perusahaan pada tahun 2015 sampai tahun 2019 menunjukan kecencerungan penurunan biaya modal rata-rata tertimbang (WACC). Hal ini sangat membantu perusahaan untuk dapat mencetak EVA yang positif, sehingga dapat memberikan nilai tambah ekonomis bagi perusahaan.

\section{Capital Charger}

Tabel 5 Perhitungan Capital Charger

\begin{tabular}{|c|c|c|c|}
\hline Tahun & WACC & $\begin{array}{c}\text { Invested } \\
\text { Capital }\end{array}$ & Capital Charger \\
\hline$(1)$ & \multicolumn{1}{c|}{$(2)$} & $(3)$ & $(4=2 * 3)$ \\
\hline 2015 & -997.86 & 24950617 & -24897176813.61 \\
\hline 2016 & 885.61 & 26962838 & 23878494286.12 \\
\hline 2017 & -3212.68 & 25384652 & -81552658118.41 \\
\hline 2018 & -1303.23 & 23862913 & -31098850323.57 \\
\hline 2019 & -388.59 & 23058359 & -8960331121.67 \\
\hline
\end{tabular}

Sumber : Data diolah, 2020

Dari perhitungan Capital Charges diatas dapat dilihat pada tahun 2015 Capital charges sebesar Rp. 24.897.176.813,61 dan pada tahun 2016 Capital charges sebesar Rp. 23.878.494.286,12. Sedangkan pada tahun 2017 - 2019 capital charger PT. Indocement Tunggal Prakarsa Tbk sebesar masing-masing Rp. 81.552.658.118,41, Rp. 31.098.850.323,57 dan Rp. 8.960.331.121,67.

\section{EVA}

Tabel 6 Hasil Perhitungan EVA

\begin{tabular}{|c|c|c|c|}
\hline Tahun & NOPAT & $\begin{array}{c}\text { Capital } \\
\text { Charger }\end{array}$ & EVA \\
\hline$(1)$ & $(2)$ & $(3)$ & $(4=2-3)$ \\
\hline 2015 & 5671654 & -24897176814 & $24,902,848,467.61$ \\
\hline 2016 & 3882142 & 23878494286 & $(23,874,612,144.12)$ \\
\hline 2017 & 1873911 & -81552658118 & $81,554,532,029.41$ \\
\hline 2018 & 1164598 & -31098850324 & $31,100,014,921.57$ \\
\hline 2019 & 1181678 & -8960331122 & $8,961,512,799.67$ \\
\hline
\end{tabular}

Sumber : Data diolah, 2020

\section{Analisis kinerja keuangan berdasarkan Economic Value Added (EVA)}

NOPAT Perusahaan dapat dikatakan baik apabila NOPAT yang diperoleh perusahaan bernilai positif atau lebih besar dari biaya modal (Capital chargers) perusahaan tersebut. Berdasarkan tabel 2 diatas Hasil perhitungan NOPAT menunjukan PT. Indocement Tunggal Prakarsa Tbk adalah baik dalam kegiatan operasi usahanya. Hal ini terlihat dari NOPAT yang 


\section{Meiske Wenno}

dihasilkan pada tahun 2015 - 2019 walaupun mengalami penurunan tetapi menghasilkan nilai positif, dikarenakan EAT yang diperoleh PT. Indocement Tunggal Prakarsa Tbk menghasilkan laba. Selain itu NOPAT yang diperoleh perusahaan selama tahun 2017 dan 2018 lebih kecil dari biaya modal yang digunakan oleh PT. Indocement Tunggal Prakarsa Tbk NOPAT yang negative atau lebih kecil dari biaya modal (Capital charges) akan memberikan berdampak buruk terhadap EVA yang diperoleh perusahaan karena akan menghasilkan EVA yang negative $($ EVA $<0)$. Artinya PT. Indocement Tunggal Prakarsa Tbk kurang optimal dalam melakukan kegiatan operasional perusahaan untuk menghasilkan laba.

Dari hasil perhitungan tabel 3 diatas menujukan bahwa Capital charges tahun 2015 2019 mengalami penurunan setiap tahunnya. Selain itu juga nilai Capital Charges yang diperoleh PT. Indocement Tunggal Prakarsa Tbk pada tahun 2015,2016 dan 2019 lebih kecil dari NOPAT yang memberikan manfaat bagi perusahaan untuk menciptakan nilai EVA yang positif karena Semakin kecil nilai Capital Charge akan memberikan dampak menaikkan nilai EVA sehingga proses penciptaan nilai akan meningkat. Sedangkan nilai capital charger yang dicapai PT. Indocement Tunggal Prakarsa Tbk pada tahun 2017 dan 2018 lebih besar dari NOPAT yang akan berdampak buruk bagi nilai EVA artinya PT. Indocement Tunggal Prakarsa Tbk kurang baik dalammengelola biaya modalnya.

Berdasarkan tabel 6 diatas dapat dijelaskan bahwa EVA PT. Indocement Tunggal Prakarsa Tbk selama tahun 2015, 2016 dan 2019 memiliki nilai positif (EVA > 0) yang beararti kinerja keuangan perusahaan dapat dikatakan baik pada tahun tersebut, sehingga terjadi proses perubahan nilai ekonomisnya. Sedangkan hasil EVA PT. Indocement Tunggal Prakarsa Tbk di tahun 2017 dan 2018 menunjukan nilai EVA yang negative (EVA $<0$ ) yang berarti kinerja keuangan perusahaan pada periode ini dapat dikatakan tidak baik. Hal ini menunjukan bahwa EVA mengalami kerugian yang cukup berarti sehingga perusahaan tidak berhasil menciptakan nilai tambah bagi investor. Keadaan EVA ditahun 2017 dan 2018 yang menghasilkan nilai negative $(E V A<0)$ disebabkan oleh perubahan nilai NOPAT dan nilai capital charges dimana lebih kecilnya nilai NOPAT dibandingkan nilai Capital Charges. Kecilnya nilai NOPAT disebabkan oleh penurunan laba perusahaan dan meningkatnya beban bunga perusahaan pada tahun 2017 dan 2018.

\section{Kesimpulan}

Berdasarkan hasil analisis kinerja keuangan dengan menggunakan pendekatan rasio keuangan dan Economic Value Added (EVA) maka dapat disimpulkan:

1. Current ratio PT. Indocement Tunggal Prakarsa Tbk sangat baik yang berarti perusahaan mempunyai kemampuan untuk memenuhi kewajiban lancar dari aktiva lancar. Quick ratio PT. Indocement tunggal prakarsa tbk juga sangat baik karena berada di atas $150 \%$ yang berarti perusahaan sangat mampu untuk memenuhi kewajiban jangka pendeknya dengan aktiva lancar yang dimiliki di luar persediaan.

2. Debt to asset ratio PT. Indocement tunggal prakarsa tbk dalam kondisi baik karena memiliki nilai rasio yang kecil yang berarti semakin sedikit perusahaan dibiayai oleh hutang. Debt to equity ratio PT. Indocement Tunggal Prakarsa Tbk juga dalam kondisi baik. Nilai DER yang rendah menunjukan hutang atau kewajiban perusahaan lebih kecil dari seluruh asset yang dimiliki. 
3. Inventory turn over ratio PT. Indocement Tunggal Prakarsa Tbk menunjukan kinerja yang tidak baik karena perputaran persediaan yang rendah atau terjadinya penumpukan persediaan barang yang dipoduksi atau dijual. Fixed asset turn over ratio juga tidak baik karena mengalami penurunan selama periode penelitian, nilai rasio yang sangat kecil menunjukan perusahaan belum efektif dalam mengelola asset tetapnya untuk menghasilkan pendapatan. Total Asset Turn Over Ratio PT. Indocement Tunggal Prakarsa Tbk juga menunjukan kinerja yang tidak baik karena perusahaan tidak efisien menghasilkan penjualan dari total asset yang dimiliki. Semakin kecil rasio ini semakin tidak baik bagi perusahaan karena aktiva perusahaan berputar lambat menghasilkan laba atau perusahaan tidak efisien menggunakan total aktiva untuk menghasilkan penjualan.

4. Net profit margin (NPM) PT. Indocement Tunggal Prakarsa Tbk menunjukan penurunan setiap tahunnya. Penurunan rasio NPM yang drastis pada tahun 2018 mengindikasikan meningkatnya biaya tidak langsung yang relative tinggi terhadap penjualan dan beban pajak yang tinggi pada periode tersebut. Return on equity ratio PT. Indocement Tunggal Prakarsa Tbk mengalami menurunan selama periode penelitian, menunjukan kinerja perusahaan yang kurang baik. Penurunan nilai rasio ini setiap tahunnya menunjukan pengembalian investasi yang mengalami penurunan dari tahun ke tahun. Return on investment PT. Indocement Tunggal Prakarsa Tbk selama periode penelitian juga belum baik. Penurunan nilai ROI setiap tahunnya menunjukan kinerja yang tidak baik karena terjadi penunurunan hasil pengembalian investasi perusahaan yang menunjukan ketidakmampuan manajemen untuk menghasilkan keuntungan.

5. EVA PT. Indocement Tunggal Prakarsa Tbk selama tahun 2015, 2016 dan 2019 memiliki nilai positif (EVA > 0) yang berarti kinerja keuangan perusahaan dapat dikatakan baik pada tahun tersebut, sehingga terjadi proses perubahan nilai ekonomisnya. Sedangkan hasil EVA PT. Indocement Tunggal Prakarsa Tbk di tahun 2017 dan 2018 menunjukan nilai EVA yang negative $(E V A<0)$ yang berarti kinerja keuangan perusahaan pada periode ini dapat dikatakan tidak baik. Hal ini menunjukan bahwa EVA mengalami kerugian yang cukup berarti sehingga perusahaan tidak berhasil menciptakan nilai tambah bagi investor.

Saran dari penelitian ini adalah sebagai berikut:

1. Rasio likuiditas pada Current ratio dan Quick ratio berada pada kategori kinerja yang baik. Namun tetap harus diperhatikan oleh pihak manajer bahwa terlalu tinggi rasio ini menunjukan terlalu banyak dana yang menganggur di bank yang menyebabkan perusahaan kehilangan kesempatan untuk mendapatkan keuntungan yang lebih besar.

2. Rasio leverage pada rasio debt to asset ratio dan debt to equity ratio dalam kondisi yang baik, sebaiknya perusahaan mempertahan kinerja yang baik agar periode berikutnya dengan memperhatikan komposisi penggunaan modal dan dana pihak ketiga.

3. Rasio aktivitas pada rasio perputaran persediaan dalam kondisi yang tidak baik sebaiknya perusahaan harus memperhatikan pengelolaan stock barang dengan baik, yang berdampak untuk memenuhi kebutuhan pelanggan dan meminimalisir biaya yang harus dikeluarkan. Pada rasio fixed asset turn over dalam kinerja yang tidak baik, sebaiknya perusahaan kembali harus melhat terdapat kapasitas yang terlalu besar dan melihat asset tetap yang tidak bermanfaat, perusahaan harus mengurangi investasi pada aktiva tetap yang berlebihan jika dibandingkan dengan nilai output yang diperoleh. Pada rasio perputaran total aktiva dalam kinerja yang tidak baik dan tidak efisien, sebaiknya pihak manajemennya harus efisien dalam menggunakan assetnya dengan baik, dengan kata lai pengelolaan manajemen harus berperan penting dalam hal ini. 


\section{Meiske Wenno}

4. Rasio profitabilitas pada rasio net profit margin dalam kinerja yang tidak baik, sebaiknya perusahaan harus menekan biaya biaya seperti hpp, bunga pajak dan depresiasi lainya,pada rasio retrun on equity dalam kondisi kinerja yang tidak baik, sebaiknya perusahaan harus menambah modal yang besar agar dapat menghasilkan ROE yang besar. Pada rasio retrun on investment dalam kondisi kinerja yang tidak baik, sebaiknya perusahaan harus lebih efisien didalam penggunaan modal kerja, produksi, hingga penjualan untuk meminimalisir kerugian di dalam investasi.

5. EVA yang dicapai perusahaan negative hendaknya dapat dikelola oleh para manajer, bahwa sebaiknya manajer berfikir dan juga bertindak seperti halnya pemegang saham yaitu memilih investasi yang memaksimumkan tingkat pengembalian dan meminimumkan tingkat biaya modal sehingga nilai perusahaan dapat dimaksimumkan.

\section{Daftar Pustaka}

Halim, Abdul dan Mamduh M. Hanafi. 2009. Analisis Laporan Keuangan. Edisi 4. UPP STIM YKPN. Yogyakarta.

Isti Fadah, Markus Apriono, M. S. (2005). Analisis Rasio-Rasio Keuangan Sebagai Dasar Penilaian Terhadap Kinerja Keuangan Perusahaan Pada Industri Barang Konsumsi Yang Listed Di Bursa Efek Jakarta. Jurnal Ekonomi Modernisasi, 1(1), 47-55. https://doi.org/10.21067/jem.v1i1.888

Kasmir. (2008). No Title. In analisis laporan keuangan. jakarta: Rajawali.

Kerihi, A. S. Y. (2019). ANALISIS KINERJA KEUANGAN PADA SWALAYAN SUMBER MAKMUR KOTA KUPANG. 7(1).

Mulyadi (2007). Sistem perencanaan dan pengendalian manajemen: sistem pelipatganda kinerja perusahaan. Jakarta: Salemba Empat.

Munawir, S. 2010. Analisis laporan Keuangan Edisi Keempat. Cetakan Kelima Belas. Yogyakarta: Liberty

Riyanto, Bambang. 2002. Dasar-Dasar Pembelanjaan Perusahaan. Edisi keempat. Cetakan keenam. Yogyakarta: BPFE

Rudianto. 2006. Akuntansi Manajemen. Jakarta: PT Gramedia.

Agnes Sawir, 2001. Analisis Kinerja Keuangan dan Perencanaan Keuangan Perusahaan, Jakarta: Gramedia Pustaka Utama

Sulistyowati, N. W. (2015). ANALISIS LAPORAN KEUANGAN SEBAGAI ALAT UNTUK MENILAI KINERJA KEUANGAN PT PELABUHAN INDONESIA III SURABAYA. Assets: Jurnal Akuntansi Dan Pendidikan, 4(2), 99-107. https://doi.org/10.25273/jap.v4i2.681

Wibowo, S. B. (2013). Analisis Rasio Keuangan Sebagai Alat Ukur Kinerja Perusahaan Pada Pt. Astalia Millenia Educatindo Cabang Madiun. Assets: Jurnal Akuntansi Dan Pendidikan, 2(1), 25.https://doi.org/10.25273/jap.v2i1.558

www.idx.co.id Laporan Keuangan PT.Indocement Tunggal Prakarsa Tbk.Tahun 2015-2019 